\title{
pÿTransboundary Environmental Harm in the Arctic In Search of Accountability for an Oil Spill
}

\section{Penttilä, Outi Riikka}

2019-01-01

pÿPenttilä , O R 2019 , ' Transboundary Environmental Harm in the Arctic In Search of Accountability for an Oil Spill ' , Yearbook of Polar Law , vol. 10 , no. 1 . https://doi.org/10.1163/22116427_01001001

http://hdl.handle.net/10138/325599

https://doi.org/10.1163/22116427_010010010

unspecified

acceptedVersion

Downloaded from Helda, University of Helsinki institutional repository.

This is an electronic reprint of the original article.

This reprint may differ from the original in pagination and typographic detail.

Please cite the original version. 


\title{
Transboundary Environmental Harm in the Arctic - In Search of Accountability for an Oil Spill
}

\author{
Outi Penttilä*
}

\section{Abstract}

Recently, the Arctic has transformed from a peripheral region to an area of great interest, for instance in terms of oil drilling. Nonetheless, no legal instrument has addressed the matter of accountability for transfrontier oil pollution damage. This article accordingly evaluates whether the current legal constructs, meaning State responsibility, international liability, civil liability regimes, and multilateral environmental agreements, allow accountability to be established for transboundary environmental harm resulting from hydrocarbon exploitation in the Arctic. It also examines whether these constructions could serve as the basis for future legislative actions. This article treats these four constructions as layers of accountability. After examining all of the layers in their current formulation, this article asserts that the existing layers cannot establish accountability for transboundary environmental damage in the Arctic, nor do they as such offer an effective way to regulate accountability in the future. Therefore, the article concludes that the law of accountability necessitates a new approach, such as a non-compliance mechanism or hybrid system combining elements of multiple layers. Finally, the article calls for immediate legislative actions.

Keywords: environmental liability, transboundary environmental damage, oil drilling, the Arctic

\section{Introduction}

Blowout. Gusher. Wild well. Across the whole region, the natural systems shudder. Months to control it. Years to get over it. Human lives changed by the hundreds of thousands. Effects that ripple across the country, the hemisphere, the world. [...] No amount of money enough. Beyond payable. ${ }^{1}$

As evidenced by the account of the Deepwater Horizon disaster, ${ }^{2}$ a drilling-related oil spill is always devastating, even if it occurs in fairly temperate conditions and relatively close to shore. In terms of

\footnotetext{
* Outi Penttilä, Doctoral Candidate, University of Helsinki, outi.penttila@ helsinki.fi.

${ }^{1}$ C Safina, A Sea in Flames: The Deepwater Horizon Blowout (Crown Publishing Group, New York 2011$) 4$.

2 National Oceanic and Atmospheric Administration, 'Natural Resource Damage Assessment, Status Update for the Deepwater Horizon Oil Spill' (April 2012) <http://www.gulfspillrestoration.noaa.gov/sites/default/files/wpcontent/uploads/FINAL_NRDA_StatusUpdate_April2012.pdf> accessed 28 December 2017.
} 
Arctic oil drilling, however, these attributes are unlikely to be met. Due to its peripheral location, long distances to the closest coastguard establishments, the fact that oil evaporates slowly in the cold, the characteristic long and harsh winters, not to mention the fragile and unique environment, the region faces a severe risk of environmental damage of the most disastrous and long-lasting kind in the event of an accident. ${ }^{3}$ Yet, the exploitation of the hydrocarbon resources in the Arctic has already commenced and its total cessation seems implausible despite the recent activities of certain Arctic States. ${ }^{4}$ Although the likelihood of a large-scale accident is small, the consequences would be catastrophic. The current legal regimes, namely the International Convention on Oil Pollution Preparedness, Response and Co-Operation, the Agreement on Co-Operation on Marine Oil Pollution, Preparedness and Response in the Arctic, or the Polar Code, ${ }^{5}$ do not regulate accountability for pollution caused by offshore oil rigs, pipelines, or other production systems. ${ }^{6}$ Instead, they concern the prevention and elimination of marine pollution by taking responsive actions should damage occur. ${ }^{7}$ Therefore, this article examines the changes in international law to enforce accountability for transboundary environmental harm resulting from oil drilling in the Arctic.

The article presents a twofold aim: First, it examines the existing legal constructions on which international accountability for transboundary harm could be based and systematises them. In order to accomplish this task in a well-structured manner, it follows Jutta Brunneé's conception of accountability for environmental damage. She divides accountability into four layers: State responsibility, State liability, civil liability regimes, and multilateral environmental agreements

\footnotetext{
${ }^{3}$ M Byers, International Law and the Arctic (CUP, Cambridge 2013), 200; WWF Report, 'Drilling for Oil in the Arctic: Too Soon, Too Risky', 1 December 2010, 7-8.

${ }^{4}$ The former US President Barack Obama announced a ban on Arctic drilling during the final weeks of his presidency; however, this ban has already been questioned by his successor, President Trump. See C Davenport, 'Obama Bans Drilling in Parts of the Atlantic and the Arctic' The New York Times (20 December 2016); R Meyer, 'Can Trump Reverse Obama's Arctic-Drilling Ban?' The Atlantic (21 December 2016). The oil companies have not admitted defeat. See R Milne, 'Statoil will not give up on exploration in Arctic' Financial Times (30 October 2017).

${ }^{5}$ International Convention on Oil Pollution Preparedness, Response and Co-Operation (adopted 30 November 1990, entered into force 13 May 1995) 1891 UNTS (OPPC); Agreement on Co-Operation on Marine Oil Pollution Preparedness and Response in the Arctic (adopted 15 May 2013, not in force); International Code for Ships Operating in Polar Waters (adopted 15 May 2015, entered into force 1 January 2017) MEPC 68/21/Add.1 (Polar Code).

${ }^{6}$ Byers (n 3) 210. Freestone notes that accountability for transboundary environmental harm remains uncovered even though such disasters frequently occur (D Freestone, 'Series Editor's Preface' in J Barboza, The Environment, Risk and Liability in International Law (Martinus Nijhoff Publishers, Leiden/Boston 2011), xiii). Interestingly, an international convention regulating the liability for oil spills is a topic that traditionally emerges in the aftermath of an incident; however, no conclusion has been reached (see J Allen, 'A Global Oil Stain - Cleaning up International Conventions for Liability and Compensation for Oil Exploration/Production', (2011) 25 Australian \& New Zealand Maritime Law Journal 90, 91.

${ }^{7}$ OPPC (n 5) Preamble; Agreement on Cooperation on Marine Oil Pollution, Preparedness and Response in the Arctic (n 5) art 1; Polar Code (n 5) Part II-A, ch 1.
} 
(MEAs). ${ }^{8}$ Second, this article concentrates on whether these layers offer ways to proceed with establishing a future accountability regime for transboundary environmental harm resulting from oil exploration.

With regard to the applied terminology, the article understands the Arctic region to encompass the Arctic Circle but including also "Iceland's northern maritime zones". 9 Additionally, the article adopts the term "accountability", by which it refers to all four layers of environmental accountability, thus encompassing State responsibility, international liability, civil liability, and MEAs. ${ }^{10}$ The controversial terms "liability" and "responsibility" are used in the manner in which the International Law Commission (ILC) has utilised them, denoting that "responsibility" only refers to State responsibility and "liability" to State liability. ${ }^{11}$ Furthermore, the terms "transfrontier" and "transboundary" are used interchangeably, like the terms "environmental damage" and "environmental harm". ${ }^{12}$ In terms of the "environment", the article adopts a broad definition: it extends from damage to natural resources, such as water, fauna, and flora, to property, landscape, and environmental amenity. ${ }^{13}$

The division of layers as the elements of international accountability serves as the structure of the article: it navigates through the different means of accountability, in the present article known as layers. Part 2 addresses State responsibility, while part 3 proceeds with international liability. Part 4 discusses civil liability regimes, and the article introduces the relevant MEAs in part 5. In each of the upcoming parts, the essentials of the legal regime at hand are examined and considerable attention is paid to the de lege ferenda aspect of that regime. ${ }^{14}$ Finally, the article concludes by evaluating the

8 J Brunnée, 'Of Sense and Sensibility: Reflections on International Liability Regimes as Tools for Environmental Protection' (2004) 53 ICLQ, 351, 351-352. For another analysis, see R Lefeber, Transboundary Environmental Interference and the Origin of State Liability (Kluwer International Law, The Hague 1996) 13-17.

${ }^{9}$ RL Johnstone, Offshore Oil and Gas Development in the Arctic under International Law: Risk and Responsibility (Brill, Leiden/Boston, 2015), 8.

${ }^{10}$ The term has been adopted for clarity's sake: responsibility and liability refer to the first two layers, State responsibility and international liability. These terms have been used in a certain context within the ILC projects, implying certain legal connotations; hence the adoption of a completely new term.

${ }^{11}$ In terms of the civil liability systems and MEAs, the terms are used in the form in which they can be found in the regime in question. See e.g. United Nations Convention on the Law of the Sea (adopted 10 December 1982, entered into force 16 November 1994) 1833-1835 UNTS 3 (UNCLOS) arts 139 and 235.

12 There are fine distinctions between these concepts: "harm" usually refers to physical and "damage" to financial consequences (Lefeber (n 8) 16).

${ }^{13}$ P Sands and J Peel with A Fabra and R MacKenzie, Principles of International Environmental Law (3rd edn CUP, Cambridge 2012) 706.

${ }^{14}$ As Koskenniemi underlines, distinguishing the approaches of de lege lata and de lege ferenda in international law is traditionally challenging. Thereby, an evaluation of the existing regimes coexists with the comments on the future 
successfulness of the existing regimes to meet the challenge posed by transfrontier environmental damage (part 6).

\section{Layer 1 - State Responsibility}

\subsection{State Responsibility for Internationally Wrongful Acts and Its Relationship to Natural Resources}

The ILC's project on State responsibility culminated in the acceptance of the Draft Articles on Responsibility of States for Internationally Wrongful Acts (ARSIWA) in 2001. ${ }^{15}$ The final codification enjoys wide-spread acceptance, ${ }^{16}$ and it incorporates the ubiquitous principle that "[e]very internationally wrongful act of the States entails the international responsibility of that State". ${ }^{17}$ Article 2, respectively, encompasses the idea that an internationally wrongful act of a State exists when certain conduct, either act or omission, is both attributable to that State and constitutes a breach of its international obligation. The criteria laid out in article 2 comprise the two main elements of State responsibility as understood in the ARSIWA. ${ }^{18}$ However, some confusion persists in terms of whether or not circumstances precluding wrongfulness constitute an additional element. ${ }^{19}$

Pursuant to article 2, responsibility is only triggered by a breach of an obligation, meaning that the acts or omissions entailing responsibility must be deemed illegal. Utilisation of offshore natural resources, however, is in principle legal: a State has permanent sovereignty over its natural resources, including a duty not to cause harm to others. ${ }^{20}$ Therefore, a State is free to exploit the resources under

\footnotetext{
prospects of the regimes to establish accountability for oil pollution. This approach increases the effect of the researcher's personal views and the chosen angle, in this case environmental, on the final results. M Koskenniemi, 'Valtion kansainvälinen vastuu yksityisen toiminnan aiheuttamasta kansainvälisestä ympäristövahingosta' (1982) Ympäristöalan tutkielmia $1,13$.

${ }^{15}$ ILC, 'Report of the International Law Commission on the Work of its 53rd Session' (23 April-1 June and 1 July-10 August 2001) UN Doc. A/56/10 (2001), paras. 76 (ARSIWA); para. 77 (Commentary).

${ }^{16}$ J Crawford, State Responsibility: The General Part (CUP, Cambridge 2013) 87-88.

${ }^{17}$ The principle has been applied in multiple cases: see e.g. Phosphates in Morocco (Preliminary Objections) [1938] PCIJ Series A/B No 74 10, 28; Corfu Channel Case (UK v Albania) (Merits) [1949] ICJ Rep 4, 23.

${ }^{18}$ ARSIWA with commentaries (n 15) 34; B Stern, 'The Elements of an Internationally Wrongful Act' in J Crawford, A Pellet, S Olleson (eds), K Parlett (asst ed), The Law of International Responsibility (OUP, New York 2010) 201; Crawford (n 16) 94.

${ }^{19}$ ARSIWA (n 15) Chapter 5; also L Condorelli and K Kress, 'The Rules of Attribution: General Considerations' in J Crawford, A Pellet, S Olleson (eds), K Parlett (asst ed), The Law of International Responsibility (OUP, New York 2010) 224. Cf. Stern (n 18) 217-218; Crawford (n 16) 274-321.

${ }^{20}$ UNGA Res 423 (VI) (1950) (4 December 1950); UNGA Res 626 (VII) (21 December 1952); UNGA Res 837 (IX) (1954) (14 December 1954); UNGA Res 1314 (XIII) (1958) (12 December 1958); UNGA Res 1515 (XV) (1960) (15 December 1960); Trail Smelter arbitration (United States v. Canada) (1941) 3 RIAA 1907; Declaration of the United
} 
its jurisdiction in a manner it chooses appropriate. In terms of ownership of marine resources, the legal framework applicable to their utilisation can be found in the UNCLOS. ${ }^{21}$ As the exploitation of natural resources constitutes a legal activity, nothing in the present law of State responsibility prohibits employing that right over one's natural resources as such. This constitutes a problem when examining the relationship between responsibility and exploitation of natural resources: industrial production, agriculture, and traffic almost unavoidably result in harm to the environment but to ensure the wellbeing of humankind, these industrial activities are considered necessary. ${ }^{22}$

Moreover, should the exploitation of natural resources contain a risk of hazardous consequences, it is traditionally subject to a licensing system. Quite naturally, oil drilling constitutes an illustration of this practice. ${ }^{23}$ Most of the Arctic States have enacted sufficient safety provisions when allowing drilling activities, despite one prominent exception, Russia, whose "environmental protection record leaves much to be desired". ${ }^{24}$ It is still difficult to imagine drilling activities being undertaken without the State in question being familiar with the extractive operation and even promoting it.

\subsection{The Elements of State Responsibility - Attribution and a Breach of an Obligation in Relation to Environmental Activities}

The question of attribution is the first condition of State responsibility, regulated by the second chapter of the ARSIWA. It traces back to the dilemma that no State can act by itself; instead, the States always act through individuals, physical persons. ${ }^{25}$ The respective articles postulate that conduct, including omissions, carried out by an organ of a State always constitutes an act of the State regardless of its nature and the position and character of the State organ. ${ }^{26}$ Additionally, the ARSIWA affirms that the conduct of an organ that has been empowered by the internal law to exercise governmental authority shall be considered as an act of the State, thus encompassing State responsibility for parastatal entities

or formerly State-owned companies exercising governmental authority in place of State organs. ${ }^{27}$ The

Nations Conference on the Human Environment (5-16 June 1972) UN Doc.A/CONF/48/14/REV.1, Principle 21; Declaration of the UN Conference on Environment and Development (3-14 June 1992), UN Doc.A/CONF.151/26/Rev.1, Principle 2.

${ }^{21}$ UNCLOS (n 11) arts 2; 3; 56; 76; 77; 136; 137; Annex II, art 4.

${ }^{22}$ Koskenniemi (n 14) 47.

${ }^{23}$ Ibid, 130-131.

${ }^{24}$ Byers (n 3) 200-208.

25 ARSIWA with commentaries (n 15) 40.

${ }^{26}$ ARSIWA (n 15) art 4; ARSIWA with commentaries (n 15) 40-41.

${ }^{27}$ ARSIWA (n 15) art 5; ARSIWA with commentaries (n 15) 42-43. 
bodies included in "organs" in the sense of the ARSIWA may vary from each other radically, ranging even to private companies. Certain criteria must still be fulfilled: the private company must be empowered through legislation to exercise functions that normally only belong to State organs due to their public character. The conduct that triggers State responsibility must also be linked to the exercise of governmental authority. ${ }^{28}$

Generally, international law acknowledges that acts or omissions undertaken by private individuals are not attributable to States, ${ }^{29}$ which hinders the utility of State responsibility in the context of Arctic oil drilling. Due to the growing interest in the decentralisation and consequent privatisation of formerly State-owned entities during the last few decades, the companies engaged in potentially harmful activities are usually private. ${ }^{30}$ This also applies to the enterprises active in the Arctic region. ${ }^{31}$ Despite being prima facie private, the ARSIWA provides that the conduct is attributable to a State if a) it is controlled and directed by a State (article 8) or b) carried out by an organ of a State (article 4), or c) the private entity undertaking the conduct exercises governmental authority (article 5). ${ }^{32}$

Proving attribution, however, is difficult. Article 8 necessitates a direct governmental agency relationship between the private entity and the State while the State in question must deliver specific directions or exercise explicit control over the private entity. ${ }^{33}$ In general, even the conduct of a Stateowned and State-controlled entity is not attributable to the State. ${ }^{34}$ Attribution is therefore only possible under exceptional conditions: it warrants explicit control and direction on the part of the State. ${ }^{35}$ Indeed, the level of control required from entities acting on State instructions almost parallels the effective control of a State, ${ }^{36}$ and the effective control test adopted by the international tribunals

\footnotetext{
28 ARSIWA with commentaries (n 15) 43. The commentary exemplifies such private activities: they i.e. include private security firms' acts when acting as prison guards or private-owned airlines' acts when controlling immigration (ibid). 29 Ibid, 47.

${ }^{30}$ A Kiss and D Shelton, 'Strict Liability in International Environmental Law' in TM Ndiaye and R Wolfrum (eds), Law of the Sea, Environmental Law and Settlement of Disputes: liber amicorum Judge Thomas A. Mensah (Martinus Nijhoff, Leiden/Boston 2007) 1140.

${ }^{31}$ Johnstone (n 9) 195-196. However, as Johnstone points out, a State may still be held responsible for private actions if it has failed to meet its primary obligations (ibid, 197-198). In the present article, this is addressed more in detail infra.

${ }^{32}$ ARSIWA (n 15) arts 4; 5; 8. For the priority of these rules, see L Guruswamy, 'State Responsibility in Promoting Environmental Corporate Accountability’ (2010) 21 Fordham Environmental Law Review 209, 213.

33 ARSIWA with commentaries (n 15) 47; Guruswamy (n 32) 214.

${ }^{34}$ ARSIWA with commentaries (n 15) 48. For more of the so-called "corporate veil", see e.g. Johnstone (n 9) 195-196.

${ }^{35}$ International courts have tested effective control in multiple cases: Military and Paramilitary Activities in and against Nicaragua (Nicaragua v. United States of America) (Merits) [1986] ICJ Rep 14, paras. 109, 115. Cf. Tadic Case (Judgement) ICTY-94-1 (26 January 2000), para. 117. Also Guruswamy (n 32) 214.

${ }^{36} \mathrm{R}$ McCorquodale and P Simons, 'Responsibility beyond Borders: State Responsibility for Extraterritorial Violations by Corporations of International Human Rights Law’ (2007) 70 Modern Law Review 598, 609-610.
} 
almost precludes attributing the conduct of a private individual to a State as such control over a private entity is only rarely exercised. ${ }^{37}$ An additional hindrance follows from the environmental context. As mentioned, oil drilling is traditionally regarded as a hazardous activity and thus subject to a licensing system. ${ }^{38}$ Therefore, the question of whether the mere existence of such a system equates with effective control over drilling activity should be examined. Given the stringent threshold of international tribunals, ${ }^{39}$ this remains unlikely. A State could also be deemed responsible for actions undertaken by private individuals pursuant to articles 4 and 5, especially in the context of human rights violations. According to this argument, the acceptance of certain duties imposes an obligation on the governmental authorities to ensure compliance with those duties. The primary obligations referred to must be detailed and specific. ${ }^{40}$ International environmental law, however, is characterised by a lack of such primary norms, ${ }^{41}$ a matter that diminishes the relevance of articles 4 and 5 in the Arctic context.

In addition to attribution, the ARSIWA also codified rules on breaches of international obligations. ${ }^{42}$ These breaches consist of two elements, material and temporal. ${ }^{43}$ A material breach of an obligation exists "when an act of that State is not in conformity with what is required of it by that obligation, regardless of its origin or character". ${ }^{44}$ The obligation may derive from any legal source and its content may differ ${ }^{45}$ neither does it necessitate the existence of fault. ${ }^{46}$ The material breach of an obligation is best demonstrated through a case-by-case analysis of a definite primary rule of international law, denoting that the precise formulation and meaning of the obligation in question should be enlarged on carefully ${ }^{47}$ In a temporary sense, the breach of an obligation necessitates that the chronological relationship between the act or omission and the existence of its breach is assessed. ${ }^{48}$ For a breach of an obligation to entail responsibility, the ARSIWA warrants that the State must be bound by the

\footnotetext{
37 Ibid.

${ }^{38}$ Byers (n 3) 200-208.

${ }^{39}$ E.g. Military and Paramilitary Activities in and against Nicaragua (n 35) paras. 109, 115; Tadic Case (n 35 ) para. 117.

${ }^{40}$ Guruswamy (n 32) 215.

${ }^{41}$ Ibid, 215-216; M Fitzmaurice, 'International Responsibility and Liability' in D Bodansky, J Brunnée and E Hey (eds), The Oxford Handbook of International Environmental Law (OUP, Oxford 2007) 1017.

42 ARSIWA (n 15) Chapter III.

${ }^{43}$ Crawford (n 16) 215.

${ }^{44}$ ARSIWA (n 15) art 12.

45 ARSIWA with commentaries (n 15) 55-56.

${ }^{46}$ Stern (n 18) 209-210.

${ }^{47}$ Crawford (n 16) 215-216.

${ }^{48}$ Ibid, 240.
} 
obligation at the time of the breach's occurrence. ${ }^{49}$ The ARSIWA also regulates the extension in time of the breach of an international obligation and composite acts. ${ }^{50}$

In order to examine whether a breach of an obligation exists in an environmental context, the primary environmental obligations should be known. Yet, the current state of international environmental law challenges the utility of State responsibility in an environmental context. First, the environmental documents define the term "environment" incoherently. Second, many of the core obligations of environmental law, such as the no harm rule, precautionary principle, or sustainable development, are vague and contested. Third, the clarifying jurisprudence in the field is scant. ${ }^{51}$ In terms of the relevant obligations, it must also be emphasised that a State may be held responsible for not only its acts but also for its omissions, should it fail to act diligently. ${ }^{52}$ The due diligence rule is significant to State responsibility for the actions of private entities, ${ }^{53}$ especially in relation to the duty not to cause harm. ${ }^{54}$ As the commentary to the ARSIWA postulates, the rules of attribution "have a cumulative effect, such that a State may be responsible for the effects of the conduct of private parties, if it failed to take necessary measures to prevent those effects". ${ }^{55}$ In this regard, a diligent State is required to undertake positive measures to prevent environmental damage and punish those responsible for it. A failure to fulfil these obligations may entail State responsibility. ${ }^{56}$

Even though the emerging environmental obligations or the obligation of due diligence could serve as the basis for responsibility-related claims against the sponsoring State, the effectiveness of such claims in front of international tribunals is subject to some controversy. The precautionary principle, for instance, has been invoked by the parties in multiple cases; yet the tribunals long hesitated to declare its status. ${ }^{57}$ Additionally, as States are recognised as the primary subjects of international law,

\footnotetext{
49 ARSIWA (n 15) art 13.

${ }^{50}$ Ibid, arts 14-15.

51 Fitzmaurice (n 41) 1017; Brunnée (n 8) 354; C Nègre, 'Responsibility and International Environmental Law' in J Crawford, A Pellet, S Olleson (eds), K Parlett (asst ed), The Law of International Responsibility (OUP, New York 2010) 805. For an assessment of the relevant obligations and their utility in the context of Arctic oil pollution damage, see $\mathrm{O}$ Penttilä, Transboundary Environmental Harm in the Arctic: A Study of Accountability for an Oil Spill (Master's thesis, 2015) 29-48.

52 Johnstone (n 9) 197-198.

${ }^{53}$ R Pisillo-Mazzeschi, 'The Due Diligence Rule and the Nature of the International Responsibility of States' (1992) 35 GYBIL 9, 40.

${ }^{54}$ Johnstone (n 9) 244-245.

55 ARSIWA with commentaries (n 15) 39.

56 Pisillo-Mazzeschi (n 53) 40-41.

${ }^{57}$ For the practice of e.g. the International Court of Justice, see e.g. Gabčíkovo-Nagymaros Project (Hungary/Slovakia) [1997] ICJ Rep 7, para. 97; Pulp Mills on the River Uruguay (Argentina v. Uruguay) (Judgement) [2010] ICJ Rep 14,
} 
the litigation processes can only be initiated by other States. Considering that States have demonstrated certain hesitancy in filing environmentally-focused complaints, ${ }^{58}$ it seems rather optimistic to expect that States would file complaints pertaining to either other States' acts or failures to act. As a consequence, the utility of State responsibility in establishing accountability for the transboundary environmental harm in the Arctic remains contested.

\subsection{Does State Responsibility Constitute an Effective Tool When Establishing Accountability} for Transfrontier Harm?

Apart from attribution and establishing the breach of an obligation, the regime of State responsibility faces other difficulties in enforcing accountability: pursuant to international law, only States are entitled to bring responsibility-related claims. States, however, have not been eager to initiate proceedings against other States, arguably fearing to expose themselves to future claims and disadvantageous rulings. ${ }^{59}$ Moreover, it is difficult to present claims for accountability for the damage caused to the global commons in accordance with the rules of State responsibility. A State has only limited means to pursue claims in cases where it is not the injured party, directly affected by the damage; in other words, a State can effectively pursue only its own standing. ${ }^{60}$ Finally, the regime of State responsibility enforces the international standards of environmental protection insufficiently, which has led to the creation of treaty-based compliance methods. ${ }^{61}$ The rationale behind the shortcomings of the regime of State responsibility to cover environmental damage can be traced to the reluctance of States to be objects of moral condemnation. State responsibility necessitates a moralistic judgement relating to the act or omission behind the harm, a fact the sovereign States have naturally accepted only cautiously. ${ }^{62}$ Responsibility is still not totally devoid of importance in environmental issues as it may be the only available means to enforce customary norms. The alternative methods, such as civil liability regimes, might also prove inadequate in upholding accountability due to their own characteristics; thus, retaining the option of recourse through

para. 164. Cf. 'Responsibilities and Obligations of States Sponsoring Persons and Entities with Respect to Activities in the Area' (No 17) (Advisory Opinion, 1 February 2011) ITLOS Reports 2011, 10, para. 127.

${ }^{58}$ P Sands, 'The Environment, Community and International Law' (1989) 30 Harvard International Law Journal 393 , 407. See also Sands' account of the State practice after the Chernobyl disaster. Even though a few States reserved a right to bring damage-related claims against the Soviet Union, no lawsuits were filed (ibid, 405-406).

${ }^{59}$ Ibid.

${ }^{60}$ Fitzmaurice (n 51) 1017-1018; 1020-1022. See also Johnstone (n 9) 213-225.

${ }^{61}$ P Birnie, A Boyle and C Redgewell, International Law and the Environment (3rd edn OUP, Oxford 2009$) 237$.

${ }^{62}$ Koskenniemi (n 14) 46-47. 
international proceedings is necessary. ${ }^{63}$ This means that the regime of State responsibility is characterised by both benefits and drawbacks. In the case of oil drilling in the Arctic, it presents an option to enforce accountability for environmental harm although certain factors hinder its utility.

\section{Layer 2 - State Liability ${ }^{64}$}

\subsection{The ILC's Project on International Liability and Its Successors - The Principles on} Allocation of Loss

Early in the preparation of the ARSIWA, the challenges relating to the utility of State responsibility in an environmental context were recognised; consequently, the ILC separated the project of liability for lawful acts from the State responsibility project in $1978 .{ }^{65}$ The work on International Liability for Injurious Consequences of Acts Not Prohibited by International Law was characterised by challenges right from its beginning, and the division acquired a reputation as one of the most contentious topics of international law. ${ }^{66}$ Similar cautiousness marked States' attitude towards the project. The core challenge, it appears, was the question of whether States could be held strictly liable for transfrontier damage, a matter only cautiously accepted by States. ${ }^{67}$ Unsurprisingly, the drafting history of international liability in the ILC became a time-consuming exercise, resulting finally in the subdivision of the topic into works on prevention and reparation. ${ }^{68}$ The former was concluded in 2001

\footnotetext{
${ }^{63}$ Birnie et al (n 61) 237.

${ }^{64}$ Contrary to State responsibility, State liability addresses accountability for lawful activities that are risk-intensive. Thus, no breach of an international obligation is necessitated. See Brunnée (n 8) 352.

65 The division was reasoned by claiming that State responsibility was meant to cover breaches of secondary rules whereas international liability supposedly concentrated on primary rules and obligations. Additionally, the legality of the act or omission was a central reason for the division. Finally, it was argued that '[a] joint examination of the two subjects could only make both of them more difficult to grasp'. ILC, 'Report of the International Law Commission on the Work of its 31st Session' (14 May-3 August 1979) UN Doc. A/34/10, para. 60. For discussion, see M Fitzmaurice, 'International Environmental Law as a Special Field' (1994) 25 NYIL 181, 205.

${ }^{66}$ Many scholars were critical towards the division: e.g. A Boyle, 'State Responsibility and International Liability for Injurious Consequences of Acts Not Prohibited by International Law: A Necessary Distinction?' (1990) 39 ICLQ, 1, 22; PM Dupuy, 'The International Law of State Responsibility: Revolution or Evolution?' (1989) 11 MichJIntlL 105, 113; Fitzmaurice (n 65) 203, 205-206; MB Akehurst, 'International Liability for Injurious Consequences Arising Out of Acts Not Prohibited by International Law' (1985) 16 NYIL 3, 9. Others have deemed the work more promising: e.g. G Handl, 'Liability as an Obligation Established by a Primary Rule of International Law' (1985) 16 NYIL 49, 79; DB Magraw, 'Transboundary Harm: the International Law Commission's Study of "International Liability"' (1986) 80 AJIL 305, 317318; Lefeber (n 8) 226.

${ }^{67}$ For the other elements of international liability, see Lefeber (n 8) 148-157.

68 Prevention and reparation were always elements of the project. See ILC, 'Third report on international liability for injurious consequences arising out of acts not prohibited by international law' (23 June 1982) UN Doc A/CN.4/360, para. 9.
} 
when the Draft Articles on Prevention of Transboundary Harm from Hazardous Activities were adopted, ${ }^{69}$ while the latter, more contentious project was almost abandoned by the ILC, to be resumed only after a direct request from the General Assembly. ${ }^{70}$ After reintroducing the topic, the ILC concluded its work on reparation rapidly, presumably thanks to abandoning the previous focus on strict State liability. ${ }^{71}$

After restating the matter in the ILC's agenda in 2002, the final version of the Draft Principles on Allocation of Loss in the Case of Transboundary Harm Arising out of Hazardous Activities was adopted in 2006. ${ }^{72}$ These Principles apply to transfrontier damage resulting from hazardous activities not prohibited by international law. ${ }^{73}$ They are supplementary to both the ARSIWA and the Draft Articles on Prevention. In the latter case, however, they indicate that if the State has complied with the obligation of prevention, no liability can be triggered. ${ }^{74}$ The Principles necessitate that damage inflicted on persons, property or the environment must be significant. The elements of damage include the loss or damage caused by the impairment of the environment, the costs relating to reasonable measures of reinstatement of the environment, and the costs of reasonable response measures. ${ }^{75}$ The objectives of the Principles are twofold: they aim at ensuring prompt and adequate compensation for the victims while aspiring to preserve and protect the environment. ${ }^{76}$

In terms of compensation, the Principles establish a requirement for each State to take the necessary measures to ensure prompt and adequate compensation. ${ }^{77}$ They also address the channelling of liability: the adopted measures "should include the imposition of liability on the operator or, where appropriate, other person or entity". ${ }^{78}$ In this regard, the Principles are based on the operator's

\footnotetext{
${ }^{69}$ ILC, 'Report of the International Law Commission' (n 15) para. 97 (Draft Articles on Prevention).

${ }^{70}$ UNGA Res 56/82 (12 December 2001); also A Boyle, 'Liability for Acts Not Prohibited by International Law' in J Crawford, A Pellet, S Olleson (eds), K Parlett (asst ed), The Law of International Responsibility (OUP, New York 2010) 97.

71 A Boyle, 'Globalising Environmental Liability: The Interplay of National and International Law' (2005) 17 Journal of Environmental Law 3, 6.

${ }^{72}$ ILC, 'Report of the International Law Commission on the Work of its 58th Session' (1 May-9 June and 3 July-11 August 2006) UN Doc. A/61/10, para. 66 (Principles on Allocation of Loss); para. 67 (Commentary).

73 The scope of the Principles on Allocation of Loss mirrors the scope of the ILC's work on prevention of transboundary harm. See ILC, 'Second report on the legal regime for allocation of loss in case of transboundary harm arising out of hazardous activities' (15 March 2004) UN Doc. A/CN.4/540, para. 36(2).

${ }^{74}$ Kiss and Shelton (n 30) 1138.

75 Principles on Allocation of Loss (n 72) principle 2(a)(iii)-(v).

${ }^{76}$ Principles on Allocation of Loss (n 72) principle 3; Principles on Allocation of Loss with commentary (n 72) 140-150.

${ }^{77}$ Principles on Allocation of Loss (n 72) principle 4(1).

${ }^{78}$ Ibid, principle 4(2).
} 
liability, ${ }^{79}$ and the operator is defined as the entity that uses, controls or directs, the activity. ${ }^{80}$ Furthermore, liability should not be subject to requesting proof of fault. ${ }^{81}$ The Principles also allow exonerations from liability and impose an obligation on the operators to maintain insurance or other financial security. In the event the victims still are not compensated adequately, the State of origin should guarantee access to additional financial remedies. ${ }^{82}$

The Principles additionally govern the law of response measures and offer guidance on domestic and international remedies. ${ }^{83}$ In other words, they seek to ensure that States notify other States about the effects of transboundary damage and regulate cooperation and sharing of information, as well as the obligation to take all the necessary measures to extenuate and eliminate the effects of the damage. ${ }^{84}$ States need to maintain a sufficient level of allowance to their judicial and administrative bodies to ensure the availability of effective, prompt and adequate remedies in the event of transboundary damage. The access to justice and information must be granted equally to all victims of transfrontier harm. ${ }^{85}$ Furthermore, States should promote the conclusion of additional regional agreements when possible, taking into account the participation of the relevant industry in providing supplementary funds for compensation. ${ }^{86}$ States should also adopt legislative, regulatory and administrative measures and promote cooperation in law-making. ${ }^{87}$

\subsection{Are the Principles on Allocation of Loss an Adequate Measure when Regulating} Accountability for Oil Spills in the Arctic?

The Principles on Allocation of Loss embody a range of general principles that are codified in a soft law document. Despite the adoption of this document, however, accountability for transboundary harm remains insufficiently regulated. First, this originates from the unsatisfying, soft law formulation of the Principles as the finalised Principles adopt the wording of "should" instead of "shall". ${ }^{88}$ The

\footnotetext{
${ }^{79}$ Principles on Allocation of Loss with commentary (n 72) 154-155.

${ }^{80}$ Principles on Allocation of Loss (n 72) principle $2(\mathrm{~g})$.

${ }^{81}$ Ibid, principle 4(2).

${ }^{82}$ Ibid (n 72) principles 4(2)-4(5).

${ }^{83}$ Ibid, principles 5-6. The initial formulation of principles 5 and 6 gained severe criticism due to the chosen wording: they were set out in soft law terms, a solution that was perceived inappropriate. Hence, the final wording was praised (see Boyle (n 71) 18-19; Boyle (n 70) 97; 100).

${ }^{84}$ Draft Principles on Allocation of Loss (n 72) principle 5.

${ }^{85}$ Ibid, principle 6.

${ }^{86}$ Ibid, principle 7.

${ }^{87}$ Ibid, principle 8 .

${ }^{88}$ Ibid, principles 4; 5(c); 5(e); 6(2); 7; 8. Even this is an improvement: in its earliest forms, the entire project was drafted in the form of "should" (Boyle (n 70) 100-101; Barboza (n 6) 160). See also Special Rapporteur Rao's reply to the
} 
ILC perceived it a major asset because, thanks to the adopted approach, the Principles do not necessitate the harmonisation of domestic systems. Arguably, the formulation also promotes their more widespread acceptance. ${ }^{89}$ Second, the Principles are based on the assumption of civil liability of an operator rather than State liability. In other words, States should ensure prompt and adequate compensation for the victims of transboundary damage through establishing strict liability for the operator of a hazardous activity or, where appropriate, to another person or entity. ${ }^{90}$ This feature certainly fulfils the elements of a civil liability system. ${ }^{91}$ Indeed, the ILC seems to perceive State responsibility and civil liability as "potentially complementary regimes" 92 and claims that any future work on the issue of liability should be devoted to developing civil liability regimes. ${ }^{93}$ As such, the Principles do not establish liability for the States in inter-State relationships, unless the State in question is the operator of the hazardous activity. ${ }^{94}$ The growing willingness to privatise formerly State-run industry areas, however, further minimises the chances for this, and establishing strict State liability for actions undertaken by private operators remains as questionable as ever. ${ }^{95}$

Even though promoting civil liability regimes that at least in some cases are an effective tool for combatting transfrontier damage is a respectable goal, the main anxiety still remains. When shifting the focus of the project on international liability from inter-State strict liability to operator-based civil liability, the ILC watered down the original purpose of international liability. The shift is understandable as establishing State liability faced such difficulties that its completion without altering its focus was improbable. ${ }^{96}$ Yet, hazardous activities are traditionally subject to licensing systems and thus the sponsoring State is well aware of the risks the activity contains. Due to State sovereignty, it even enjoys the capacity of regulating such an activity. Hence, providing an opportunity to outsource accountability to private actors may promote States' willingness to engage in hazardous

criticism, ILC, 'Third report on the legal regime for allocation of loss in case of transboundary harm arising out of hazardous activities' (7 March 2006) UN Doc. A/CN.4/566, 85-86.

${ }^{89}$ Principles on Allocation of Loss with commentary (n 72) 113-114. Ultimately, the relevance of the form of the draft principles must also be scrutinised: should the draft principles have been codified as draft articles, they still would have been a soft law document. Thus, any improvement in the current situation would have been controversial.

${ }^{90}$ Principles on Allocation of Loss (n 72), principle 4(2); 4(5).

${ }^{91}$ Boyle (n 70) 99; Fitzmaurice (n 41) 1032.

92 Boyle (n 70) 99.

93 ILC, 'First report on the legal regime for allocation of loss in case of transboundary harm arising out of hazardous activities' (18 March 1998) UN Doc. A/CN.4/487, para. 114. See also Johnstone (n 9) 263-264 (arguing that a failure to complete such regimes could, at least theoretically, entail State responsibility); cf. Penttilä (n 51) 91.

${ }^{94}$ Principles on Allocation of Loss with commentary (n 72) 140.

${ }^{95}$ Kiss and Shelton (n 30) 1140.

${ }^{96}$ For the Special Rapporteurs' difficulties, see Lefeber (n 8) 189-219. 
activities. Therefore, the aspiration to shy away from State liability appears questionable, especially when considered from the perspective of the environment. ${ }^{97}$

In terms of the feasibility of the Principles in the context of Arctic oil spills, similar issues must be considered. As they only comprise a non-binding soft law document, the Principles do not offer a workable solution for establishing accountability for transboundary harm. Even if binding, they would only establish an initiative to create civil liability regimes. ${ }^{98}$ Thus, the remains of the ILC's ambitious project on international liability do not seem relevant in terms of Arctic hydrocarbon exploitation.

\section{Layer 3 - Civil Liability}

\subsection{Civil Liability Regimes in International Law - Ship-Source Oil Pollution Damage System as an Example}

When the ILC finalised its work on international liability, it corroborated that any future development of environmental accountability should be based on a civil liability regime. Moreover, the general support for civil liability regimes may be derived from the accelerating number of adopted civil liability conventions, ${ }^{99}$ even though some of them have not entered nor are expected to enter into force. ${ }^{100}$ As general systems, civil liability regimes most often regulate accountability for specific, ultra-hazardous activities, such as the liability for ship-source oil pollution or nuclear activities, ${ }^{101}$ and the regimes endeavour to channel liability and costs to the owners or operators of the high-risk activities instead of States. ${ }^{102}$ Usually, they recognise the competence of the national courts, either in

\footnotetext{
${ }^{97}$ The question of whether strict State liability for transboundary environmental damage is a concept worth adopting has stimulated robust scholarly work: for those advocating it, see e.g. C O'Keefe, 'Transboundary Pollution and the Strict Liability Issue: The Work of the International Law Commission on the Topic of International Liability for Injurious Consequences Arising Out of Acts Not Prohibited by International Law' (1989-1990) 18 Denver Journal of International Law and Policy 145, 154. For those opposing it, see e.g. Magraw (n 66) 327.

${ }^{98}$ See infra, part 4.

${ }^{99}$ Sands and Peel (n 13) 737-738.

100 The most disheartening example is the ambitious Lugano Convention (Convention on Civil Liability for Damage Resulting from Activities Dangerous to the Environment (adopted 21 June 1993, not in force) 32 ILM 1228 (1993)).

${ }^{101}$ Sands and Peel (n 13) 738; Brunnée (n 8) 357. The nuclear activities are covered by conventions on the damage resulting from the peaceful use of nuclear energy and the operation of nuclear ships. See Convention on Third Party Liability in the Field of Nuclear Energy (adopted 29 July 1960, entered into force 1 April 1968, amended by the Additional Protocol of 28 January 1964 and by the Protocol of 16 November 1982) 956 UNTS 251; Vienna Convention on Civil Liability for Nuclear Damage (adopted 21 May 1963, entered into force 12 November 1977, amended by the Protocol of 29 September 1997) 1063 UNTS 265; Convention on the Liability of Operators of Nuclear Ships (adopted 25 May 1962, not in force). This section will, however, focus on the ship-source oil pollution damage system as an example of the civil liability systems.

${ }^{102}$ Brunnée (n 8) 352.
} 
the State of origin of the polluter or in the State where the damage was caused, to decide the liabilityrelated claims and establish that these decisions are enforceable in other State Parties. ${ }^{103}$ The existing regimes, such as the traditionally formulated ship-source oil pollution damage system, usually contain the following elements: the definitions of the applicable terminology, the provisions about the adopted standard of care (usually strict), the channelling of liability, the determination of the maximum liability, the possible exceptions of liability, the requirements in terms of insurances or other financial securities, and the procedural rules pertaining to the recognition and enforcement of judgements. ${ }^{104}$

The ship-source oil pollution damage system comprises three supplementary treaties, namely the Civil Liability Convention with subsequent Protocols, ${ }^{105}$ the Fund Convention, ${ }^{106}$ and the Bunker Convention. ${ }^{107}$ The incentive for their adoption was the occurrence of large-scale environmental catastrophes, such as the Torrey Canyon accident. ${ }^{108}$ The CLC, as did its first predecessor, rests on the principle that no State will be held responsible for oil pollution damage; instead, the liability has been channelled to the shipowners. The CLC is based on strict liability, ${ }^{109}$ and it requires the shipowner to maintain insurance or other financial security for oil pollution damage unless the ship is carrying less than 2,000 tons of oil in bulk as cargo. ${ }^{110}$ It is applicable to oil pollution that has been caused in a State Party's territory, including its territorial sea, and exclusive economic zone. In case the State Party has not established such a zone, the CLC is applicable in a zone the State Party has specifically determined for this purpose in accordance with the provisions of the CLC. The Convention also applies to preventive measures, wherever taken, to prevent or minimize oil pollution damage. ${ }^{111}$ The Convention defines pollution damage as loss or damage caused by the escape or discharge of oil from a ship, "provided that compensation for impairment of the environment other

\footnotetext{
${ }^{103}$ Fitzmaurice (n 41) 1024.

104 Sands and Peel (n 13) 738. For differences between the existing regimes, see A Rosas, 'Issues of State Liability for Transboundary Environmental Damage’ (1991) 60 Nordic Journal of International Law 29, 37-38.

105 International Convention on Civil Liability for Oil Pollution Damage (adopted 29 November 1969, entered into force 19 June 1975) 973 UNTS 3 as amended by Protocol of 1992 to amend the International Convention on Civil Liability for Oil Pollution Damage (adopted 27 November 1992, entered into force 30 May 1996) UNTS 1956 (CLC).

106 The International Convention on the Establishment of an International Fund for Compensation for Oil Pollution Damage (adopted 18 December 1971, entered into force 16 October 1978) 1110 UNTS 57, replaced by Protocol of 1992 to Amend the International Convention on the Establishment of an International Fund for Compensation for Oil Pollution Damage (adopted 27 November 1992, entered into force 30 May 1996) 1953 UNTS (Fund Convention).

${ }^{107}$ International Convention on Civil Liability for Bunker Oil Pollution Damage (adopted 23 March 2001, entered into force 21 November 2008) 40 ILM 1493 (2001) (Bunker Convention).

108 Sands and Peel (n 13) 746.

${ }^{109}$ CLC (n 105) art III.

${ }^{110}$ Ibid, art VII.

${ }^{111}$ Ibid, art II.
} 
than loss of profit from such impairment shall be limited to costs of reasonable measures of reinstatement actually undertaken or to be undertaken". ${ }^{112}$ The original text of the 1969 CLC did not mention the impairment of the environment; this amendment was adopted while the 1992 CLC was negotiated. Thus, the amended text indicates that damage to the environment falls within the scope of the treaty. ${ }^{113}$ The liability of the owner is not absolute: the CLC acknowledges several exemptions from liability. ${ }^{114}$ Moreover, a limitation of the maximum liability on the basis of an amount calculated with the assistance of the tonnage of the vessel is adopted. ${ }^{115}$

The reason the Fund Convention with its amendments was subscribed to was the failure of the CLC to satisfactorily regulate all the legal and financial aspects that were discussed while adopting the CLC. ${ }^{116}$ The main goal of the Fund Convention is to provide an additional source of compensation for the victims; therefore, it offers compensation to only those victims of pollution damage whose claims for compensation have been addressed inadequately on the basis of the CLC system. ${ }^{117}$ The Fund Convention also aims to convey part of the financial risk and consequences of damage to the owner of the cargo, not only to the owner of the vessel. ${ }^{118}$ The Bunker Convention, respectively, was adopted to enforce civil liability for bunker-related oil leaks. It mostly replicates the principles and compromises of the CLC, imposing the strict liability for oil pollution damage to the owner of the bunker and acknowledging similar exonerations of liability. ${ }^{119}$ The Convention defines pollution damage accordingly, restricting compensation for environmental damage to "reasonable measures of reinstatement". ${ }^{120}$ Moreover, the owner of a ship whose capacity exceeds 1,000 tons is expected to maintain insurance or other financial security to cover the liability. ${ }^{121}$

As a whole, the ship-source oil pollution damage system has been described as a relative success in tackling ship-source oil pollution. ${ }^{122}$ The majority of the claims made under the civil liability system

\footnotetext{
112 Ibid, art I(6)(a).

113 Sands and Peel (n 13) 747.

${ }^{114}$ CLC (n 105) art III(2)(a).

115 Ibid, art VI(1).

${ }^{116}$ G Doeker and T Gehring, 'Private or International Liability for Transnational Environmental Damage - the Precedent of Conventional Liability Regimes' (1990) 2 Journal of Environmental Law 1, 5.

${ }^{117}$ Fund Convention (n 106) arts 2(1)(a); 4(2)-4(4).

118 Sands and Peel (n 13) 748.

${ }^{119}$ Bunker Convention (n 107) arts 3(1); 4.

120 Ibid, art 1(9)(a).

${ }^{121}$ Ibid, art 7.

${ }^{122}$ Brunnée (n 8) 366.
} 
have been met promptly and without resorting to further national litigation processes. Additionally, 92 to 95 percent of the relevant shipping nations have accessed the system, even though this excludes a number of relevant players, such as the United States. Even these States, however, have acknowledged the importance of the issue and have often concluded national legislation regulating ship-source oil pollution. ${ }^{123}$

\subsection{Is a Civil Liability Regime Feasible in Terms of Establishing Accountability for the Utilisation of Hydrocarbon Resources?}

The idea of a civil liability system for oil drilling is not novel, as regulative actions already exist in other geographical areas, such as the North Sea. There, the Convention on Civil Liability for Oil Pollution Damage Resulting from Exploration for and Exploitation of Seabed Mineral Resources regulates civil liability for damage resulting from offshore drilling activities. ${ }^{124}$ Its similarities with the ship-source pollution damage system are striking: it establishes strict liability on the operator of the installation, reiterates the rules governing the exceptions of liability, and limits the liability. ${ }^{125}$ The treaty, however, never entered into force, most probably due to its article 15, which allows States to freely determine the liability limits and thus creates an avenue for forum shopping. In other words, the latitude granted to States could result in altering the maximum liability to gain economic advantage, resulting in continuous turmoil in the regulation of oil drilling. ${ }^{126}$

To ensure maximum participation, a civil liability regime for the Arctic hydrocarbon activities would best be concluded on the basis of the existent systems and contain the traditional elements already listed: ${ }^{127}$ the applicable terminology, the channelling liability, the standard of care, the possible exonerations and limitations of liability, the requirement of financial security, and the procedural elements. Its geographical scope should also be determined. The more traditional the system, the better

\footnotetext{
${ }^{123}$ Birnie et al (n 61) 438-439.

${ }^{124}$ Convention on Civil Liability for Oil Pollution Damage Resulting from Exploration for and Exploitation of Seabed Mineral Resources (adopted 1 May 1977, not in force) 16 ILM 1450 (1977). The current signatories include Germany, Ireland, the Netherlands, Norway, Sweden and the United Kingdom. Belgium and France have not signed the Convention. Should the Convention enter into force in the future, its article 18 stipulates that the Parties could invite more States to join the regime but these States would need to "have coastlines on the North Sea, the Baltic Sea or that part of the Atlantic Ocean to the north of 360 North latitude".

125 Ibid, arts 3; 6; 7.

${ }^{126}$ M Gavouneli, Pollution from Offshore Installations (Graham\&Trotman, London 1995) 118-119.

127 See supra section 4.1.
} 
prospects it would enjoy in terms of entering into force. ${ }^{128}$ Thereby, a civil liability regime applicable to Arctic oil drilling could be welcomed, as it would assist in establishing accountability for oil pollution damage. Given the current political atmosphere, concluding such an agreement is more probable than establishing strict State liability.

Yet, even civil liability regimes incorporate challenges as the ship-source oil pollution damage regime demonstrates: First, these regimes always allow limiting and exonerating liability, meaning that the operators never compensate the damages fully. ${ }^{129}$ This is the most precarious side of such a regime. The partial compensation together with the exonerations allows the operators of a hazardous activity to benefit from not having to bear the full monetary consequences of possible damage, which can even be deemed a state subsidy to the hazardous activity. ${ }^{130}$ Second, the scope of the civil liability regimes is traditionally narrow in terms of covered activities and territorial application, meaning, for instance, that the damage that occurs beyond the exclusive economic zone is often left uncompensated. ${ }^{131}$ This is undesirable in the Arctic context as an oil spill may result in the destruction of the Area. Despite these downsides, however, civil liability systems could provide an avenue for the future law-making activities: considering the insistence of the international community on civil liability rather than State liability and the positive experiences in regulating accountability for ship-source oil pollution damage, a regime based on them appears the most realistic way to improve accountability for environmental damage.

\footnotetext{
128 The most traditionally built regimes are accepted more easily: e.g. the Bunker Convention, which reiterates much of the CLC, was adopted in 2001 and entered into force in 2008. The ambitious Lugano Convention, instead, has acquired no ratifications.

${ }^{129}$ Koskenniemi (n 14) 26-27. Considering that the civil liability schemes are based on financial securities granted by insurance companies, this is understandable: an unlimited financial burden would mean that no enterprise could offer the respective insurances.

${ }^{130}$ Byers (n 3) 211. The international community would truly invest its funds more effectively if such subsidies were granted to developing renewable energy instead of aiding a branch of industry that not only may cause serious damage but also contributes to climate change.

${ }^{131}$ Koskenniemi (n 14) 26.
} 


\section{Layer 4-Multilateral Environmental Agreements}

\subsection{MEAs Regulating Liability}

The MEAs seeking to establish accountability can be divided into those agreements that establish strict State liability for damage and those that include references to, or provisions of, liability. ${ }^{132}$ In the context of the former, only one eminent exception, the Liability for Damage Convention, ${ }^{133}$ establishes strict State liability. The Convention regulates liability for damage caused by space objects and pursuant to it, the launching State is "absolutely liable to pay compensation for damage caused by its space object either on the surface of the earth or to an aircraft in flight". ${ }^{134}$ The Convention is a unique treaty, mainly because its negotiation process was vastly influenced by all the most prominent States engaged in celestial activities. ${ }^{135}$ Its negotiations were antedated by the conclusion of the Outer Space Treaty; ${ }^{136}$ consequently, the Liability for Damage Convention is often perceived as a further elaboration of the principles codified in the previous treaty. ${ }^{137}$ Pursuant to the Convention, the damage is defined as "loss of life, personal injury or other impairment of health; or loss of or damage to property of States or of persons, natural or juridical, or property of international intergovernmental organizations". ${ }^{138}$ Notably, environmental harm as a compensable form of damage is not included; yet it has still been argued that the Convention allows such claims, interpreting "property of States" to include both the natural resources and environmental assets of a State. ${ }^{139}$ The aim of the compensation is to restore circumstances as if the harm never occurred. ${ }^{140}$ The Convention is based

\footnotetext{
${ }^{132}$ As mentioned, the layer-based construction of the article originates from Brunnée's article. The earlier sections have followed her perception slavishly. Yet, in this section, there are notable differences: the article treats the Liability for Damage Convention in this context, even though Brunnée pays no attention to it. This is surprising as the Convention is regularly included in the relevant MEAs in the literature (e.g. Doeker and Gehring (n 116) 12-14; Kiss and Shelton (n 30) 1135-1136). An additional difference pays tribute to the Basel Convention on the Control of Transboundary Movements of Hazardous Wastes and their Disposal, on which Brunnée's assessment of the fourth layer is founded. The Convention is not treated in the current section as it concentrates on imposing strict liability on the operators of the waste-related transports. In other words, the Basel Convention is a civil liability convention, and even Brunnée admits it (Brunnée (n 8) 360).

${ }^{133}$ Convention on International Liability for Damage Caused by Space Objects (adopted 29 March 1972, entered into force 1 September 1972) 961 UNTS 187 (Liability for Damage Convention).

${ }^{134}$ Ibid, art II. For exceptions, see arts VI and VII.

${ }^{135}$ Doeker and Gehring (n 116) 13.

${ }^{136}$ Treaty on Principles Governing the Activities of States in the Exploration and Use of Outer Space, including the Moon and other Celestial Bodies (adopted 27 January 1967, entered into force 10 October 1967) 610 UNTS 205 (Outer Space Treaty).

${ }^{137}$ Kiss and Shelton (n 30) 1136.

${ }^{138}$ Liability for Damage Convention (n 133) art I(a).

${ }^{139}$ Sands and Peel (n 13) 728; Rosas (n 104) 41.

${ }^{140}$ Liability for Damage Convention (n 133) art XII.
} 
on strict State liability while it channels liability to the launching State instead of the operator. ${ }^{141}$ It also includes exonerations from liability: States are allowed to depart from strict liability if the harm is a result of gross negligence or an intentional act or omission conducted by the claimant. In case the launching State has violated its international obligations and this violation has resulted in damage, no exonerations are available. ${ }^{142}$

In addition to the Liability for Damage Convention, multiple MEAs either refer to liability indirectly or contain provisions relating to it, of which this article focuses on three examples, namely the UNCLOS, the Antarctic Treaty System (ATS) and the proposed Arctic Treaty. The UNCLOS mainly concerns other topics; however, it also encompasses provisions on accountability. Article 235 imposes no additional rules on liability for environmental damage but refers to the existing rules of international law, stipulating that responsibility and liability shall be defined in accordance with international law. ${ }^{143}$ The Convention also includes a special notion of liability for deep sea-bed activities. Pursuant to article 139, States are responsible for ensuring that activities undertaken in the Area are conducted in conformity with the rules of the UNCLOS that regulate the principles governing the Area. Moreover, the damage resulting from a failure to carry out the responsibilities of a State or an organisation triggers the liability of that actor. ${ }^{144}$ Yet, the applicability of article 139 is limited. First, it only applies to activities conducted in the Area, i.e. beyond the continental shelf of a State. This excludes liability for damage arising from activities undertaken in the vicinity of the shore. Second, a State is not liable for damage caused by an entity it has sponsored if the State "has taken all necessary and appropriate measures to secure effective compliance". ${ }^{145}$ Indeed, the International Tribunal for the Law of the Sea has emphasised that no strict State liability is enforceable on the basis of the UNCLOS, noting that the "liability for damage of the sponsoring State arises only from its failure to meet its obligation of due diligence". ${ }^{146}$ Thus, the UNCLOS only effectuates a general framework of liability instead of enforcing accountability for transboundary environmental damage;

\footnotetext{
${ }^{141}$ Ibid, art II.

${ }^{142}$ Liability for Damage Convention (n 133) art VI.

${ }^{143}$ For instance, Rosas categorises the UNCLOS to treaties adopting no special liability regime (Rosas (n 104) 32).

${ }^{144}$ UNCLOS (n 11) art 139(2).

145 Ibid.

${ }^{146}$ ITLOS Advisory Opinion (n 57), para. 189.
} 
neither can it serve as the basis for establishing strict State liability. Yet, article 235(3) still encourages State parties to regulate the question of international accountability. ${ }^{147}$

Additional liability-related measures can be found in the ATS, a regime that has been effectual in regulating the activities in Antarctica. Within the ATS, liability is addressed in the CRAMRA and the Environmental Protocol's Annex VI. ${ }^{148}$ As the former never entered into force, mainly due to its stringent signature provision, ${ }^{149}$ the main instrument for liability is Annex VI to the Environmental Protocol. In many aspects, Annex VI replicates the CRAMRA, ${ }^{150}$ seeking to govern Antarctic environmental emergencies relating to scientific research, tourism or other governmental or nongovernmental use of the area. ${ }^{151}$ The liability regime consists of both operator and State liability. ${ }^{152}$ An operator is responsible for undertaking effective and prompt measures to tackle environmental emergencies relating to its activities as well as bearing the costs of such measures, ${ }^{153}$ and environmental emergencies refer to accidental incidents that have resulted or threaten to result in a significant and harmful impact on the Antarctic environment. ${ }^{154}$ Furthermore, Annex VI distinguishes liability between a State actor and non-governmental body, limiting the liability of a nongovernmental operator to "as much as possible the costs of the response action that should have been taken". ${ }^{155}$ The standard of care is strict; ${ }^{156}$ however, Annex VI allows exceptions to the liability. ${ }^{157}$ As for State liability, Annex VI mainly provides no further substantive rules on the matter, ${ }^{158}$ while excepting direct State responsibility for the activities of private operators from its purview. ${ }^{159}$ In other

\footnotetext{
147 IMO Legal Comm., Information Relating to Liability and Compensation for Oil Pollution Damage Resulting from Offshore Oil Exploration and Exploitation, 98th Sess., Agenda Item 13, Doc. No. LEG 98/13 (18 February 2011).

${ }^{148}$ Convention on the Regulation of Antarctic Mineral Resource Activities (adopted 2 June 1988, not in force) 27 ILM 868 (1988) (CRAMRA); Protocol on Environmental Protection to the Antarctic Treaty (adopted 4 October 1991, entered into force 14 January 1998) 2941 UNTS; Annex VI to the Protocol on Environmental Protection to the Antarctic Treaty, Liability Arising from Environmental Emergencies (17 June 2005, not in force) 45 ILM 5761 (Annex VI).

${ }^{149}$ CRAMRA (n 148) art 62.

${ }^{150}$ However, it has been criticised as less stringent in terms of environmental protection (see R Wolfrum, 'Liability for Environmental Damage in Antarctica: Supplement to the Rules on State Responsibility or a Lost Opportunity?' in I Buffard and G Hafner (eds), International Law between Universalism and Fragmentation: Festschrift in Honour of Gerhard Hafner (Martinus Nijhoff Publishers: Leiden/Boston 2008) 817-818). Considering that the difficulties the CRAMRA faced were attributed to the insufficient level of environmental protection, this seems ironic.

${ }^{151}$ Annex VI (n 148) art 1.

152 Ibid, arts $6 ; 10$. The operator may be governmental or non-governmental (art 2(c)).

153 Ibid, art 6(2)(b).

154 Ibid, art 2(b).

155 Ibid, art 6(2).

156 Ibid, art 6(3).

157 Ibid, arts 8-9.

158 Ibid, art 10. Also Sands and Peel (n 13) 734; Wolfrum (n 150) 822.

159 Wolfrum (n 150) 822.
} 
words, Annex VI is incapable of enforcing subsidiary State liability in the case that the operator is unwilling or incapable of achieving its obligations. ${ }^{160}$ However, State responsibility for the insufficient implementation of the obligations regulated in Annex VI is not affected. ${ }^{161}$

Finally, the much advocated, yet almost utopian idea of an Arctic treaty could assist in regulating accountability. Academically, proposals on behalf of an Arctic treaty have been frequent; indeed, in terms of the Arctic cooperation, there are few issues that have gained similar attention as the need for a comprehensive treaty system applicable to the Arctic region. ${ }^{162}$ Even though the regulative need has been acknowledged, the possible basis of the system remains controversial. ${ }^{163}$ The creation of a totally new instrument applicable to Arctic cooperation has been widely advocated. ${ }^{164}$ Most scholars argue that such an agreement should take the form of a framework convention, which would facilitate the deepening of the cooperation through additional protocols, including one for accountability. ${ }^{165}$ Were the framework convention negotiated, it should respect the already existing sovereign rights, settle the overlapping sovereignty claims in the Arctic, define the guiding principles, determine the geographical applicability of the treaty, and allow wide participation. ${ }^{166}$ Yet, no consensus over the exact content of the treaty exists and a more moderate convention built on the Arctic Council's legacy has also been promoted. ${ }^{167}$ The need for a more coherent regulative framework, applicable to the Arctic cooperation has been widely recognised academically; however, in spite of the almost unanimous academic support, ${ }^{168}$ no intergovernmental initiatives exist. Conversely, the five Arctic coastal States voiced firm opposition to such initiatives, claiming that the UNCLOS forms the primary

\footnotetext{
${ }^{160}$ Sands and Peel (n 13) 734.

161 Wolfrum (n 150) 822.

162 See T Koivurova and DL Vanderzwaag, 'The Arctic Council at 10 Years: Retrospect and Prospects' (2007) 40 University of British Columbia Law Review 121.

${ }^{163}$ The proponents can be divided into four groups: those believing in the ATS-based regime, those supporting an UNCLOS-based system, those trusting that other instruments could model for the proposed treaty regime, and those advocating a new system. The first two categories have just been introduced and the last is addressed now. For an analysis of the third, see e.g. KN Casper, 'Oil and Gas Development in the Arctic: Softening of Ice Demands Hardening of International Law' (2009) 49 National Resources Journal 825.

${ }^{164} \mathrm{~T}$ Koivurova, 'Alternatives for an Arctic Treaty - Evaluation and a New Proposal' (2008) 17 RECIEL 14, 26; D Rothwell, 'The Arctic in International Affairs: Time for a New Regime?' (2008-2009) 15 Brown Journal of World Affairs 241, 248-250; HH Hertell, 'Arctic Melt: The Tipping Point for an Arctic Treaty' (2008-2009) 21 Georgetown International Environmental Law Review 565, 586-589; Byers (n 3) 213.

165 Koivurova (n 164) 26; Rothwell (n 164) 249-250; Hertell (n 164) 586-589. Cf., Byers (n 3 ) 213.

166 Rothwell (n 164) 249-250; Hertell (n 164) 587; Koivurova (n 164) 24.

${ }^{167}$ Koivurova (n 164) 24. For alternatives, see Rothwell (n 164) 250; Hertell (n 164) 589; Byers (n 3 ) 213.

${ }^{168}$ E.g. Casper (n 163) 880; Koivurova (n 164) 26; Rothwell (n 164) 249-250.
} 
means for future cooperation. ${ }^{169}$ Therefore, an Arctic treaty in the foreseeable future appears an unlikely prospect.

\subsection{Could an MEA Solve Accountability for Drilling-Related Oil Pollution Damage?}

The Liability for Damage Convention initially constitutes a perfect model of a treaty establishing strict liability for hazardous activities resulting in transboundary damage. Arguably, it allows claims based on environmentally related damage while it provides strict State liability. It has even been extensively claimed that States have accepted the strict liability regime for environmental damage on the basis of it. ${ }^{170}$ Yet, no generalisations in relation to strict liability should be made: the Convention has a peculiar drafting history, being concluded during the Cold War and supported by both the United States and Soviet Union. Additionally, none of the countries engaged in space activities was keen to include celestial activities in the arms race due to their highly sensitive military nature. ${ }^{171}$ Space activities were considered to affect State security and military interests, not economic well-being or environmental protection, which considerably increased the ability to agree on strict liability. ${ }^{172}$ The growing interest in diminishing oil reserves hardly generates a shared understanding of the significance of strict State liability for oil pollution damage. Thus, this Convention is not a convenient precedent for accountability in relation to Arctic hydrocarbon activities.

Neither do the three other alternatives referring to accountability provide sufficient sources for its establishment. First, even though the idea of the UNCLOS as a basis for accountability for environmental harm has gained both support and criticism, ${ }^{173}$ it merely generates an obligation to create liability regimes. No accountability for Arctic oil drilling may be enforced by applying its liability provisions, and opening these provisions for renewal seems improbable.

Second, the ATS with its newest addition, Annex VI, arguably contains several promising elements in terms of accountability for oil drilling-related transboundary harm. It establishes strict liability,

\footnotetext{
${ }^{169}$ Ilulissat Declaration, 28 May 2008, Arctic Ocean Conference Ilulissat, Greenland, 27-29 May 2008.

${ }^{170}$ G Handl, 'State Liability for Accidental Transnational Environmental Damage by Private Persons' (1980) 74 AJIL $525,529$.

${ }^{171}$ Doeker and Gehring (n 116) 13-14.

172 Ibid.

${ }^{173}$ For support, e.g. H Corell, 'Reflections on the Possibilities and Limitations of a Binding Legal Regime' (2007) 37 Environmental Policy and Law 321, 321-322; C Emmett and J Stuhltrager, 'After the Ice Melts: The Need for a New Arctic Agreement' (2011-2012) 26 Natural Resources \& Environment 33, 36; Ilulissat Declaration (n 169). For criticism, see Rothwell (n 164) 248-249; Casper (n 163) 880.
} 
even for purely environmental harm, and determines damage broadly. It has also been praised for its effective governance of activities in the South Pole. ${ }^{174}$ Considering that the two Poles share many similarities, such as harsh climatic conditions, a fragile environment, and accessibility-related challenges, ${ }^{175}$ a similar system also appears practical in the Arctic. Yet, the ATS entails significant challenges as the liability-related instruments have faced difficulties in terms of entry into force. ${ }^{176}$ Moreover, the conditions of the two Poles are still different: the Arctic Ocean is a sea surrounded by continents whereas the Antarctic is a continent surrounded by an ocean. Consequently, sovereign States have long been present in the Arctic. The region has also been subjected to military presence, to which the Antarctic has never been exposed. ${ }^{177}$ Additionally, the ATS was initiated long before the commercial exploitation activities in the Antarctic area commenced or even seemed commercially viable. ${ }^{178}$ Therefore, a treaty system replicating the approach adopted in the ATS seems improbable.

Third, the Arctic treaty remains moot in terms of establishing accountability for hydrocarbon-related environmental harm, mainly because such an international instrument has not been created despite the academic effort promoting it. Were a regional framework agreement created, it remains uncertain whether it would regulate the liability for transboundary environmental damage and thus provide the essential tools for establishing international accountability. Noting the difficulties the ATS has faced, an effortless negotiation of an agreement relating to accountability in the Arctic context would constitute a major surprise. Thus, neither do the multilateral environmental treaties provide an effective tool for enforcing the international accountability for a transboundary oil spill.

\section{Conclusions}

The present article indicates that each of the layers of accountability remains a prisoner of its own limits, meaning that international law does not currently allow an effective establishment of accountability for transboundary environmental damage. Therefore, "a new way" is needed. In the

\footnotetext{
174 MA Verhaag, 'It Is Not Too Late: The Need for a Comprehensive International Treaty to Protect the Arctic Environment' (2002-2003) 15 Georgetown International Environmental Law Review 555, 578. For a more hesitant view, L Nowlan, Arctic Legal Regime for Environmental Protection (IUCN Environmental Policy and Law Paper No. 44, 2001) 66. 
literature, multiple propositions exist, ranging from compliance mechanisms that would prevent harm from occurring in the first place, ${ }^{179}$ to more flexible non-compliance mechanisms similar to the noncompliance procedure of the Montreal Protocol. ${ }^{180}$ Yet it is not entirely certain whether flexibility can and indeed should play a fundamental role when determining international accountability. Even though the compliance mechanisms may promote obedience to treaty commitments, their highly political and diplomatic nature also entails drawbacks, possibly increasing the influence of those who wield the political power in case the rule of law fails. ${ }^{181}$

While none of the layers alone provides an effective solution, albeit some are more promising than the others, the problem at hand could be solved through a hybrid system incorporating the best elements of the existing systems. For instance, the system could essentially be a civil liability system supplemented by monetary State participation. Yet, the proposed regime faces a dilemma. It should be based on an innovative and flexible approach to the issue of accountability while a more conventional regime building on the accepted elements of accountability is more likely to enter into force.

What then could trigger the drafting of a regime establishing international accountability for oil pollution damage resulting from oil drilling activities? Based on previous experiences, there are two alternatives: either creating a regime in the aftermath of a major environmental disaster, as happened in the ship-source oil pollution damage, or creating a workable system when environmental matters have become a concern of a security and military nature, as evidenced by the Liability for Damage Convention. Neither of these opportunities, however, appears tempting in the Arctic context. Allowing a transfrontier incident to occur before initiating the drafting activities, especially when the need for regulative measures has long been acknowledged, is irresponsible. Additionally, States' willingness to promote solutions for military and security threats far exceeds their readiness to tackle the sovereignty-related matters of accountability for environmental damage. The disadvantage is that

\footnotetext{
${ }^{179}$ Fitzmaurice (n 41) 1035.

180 Montreal Protocol on Substances that Deplete the Ozone Layer (adopted 16 September 1987, entered into force 1 January 1989) 1522 UNTS 3; Nègre (n 51) 808-811. The non-compliance procedures provide an alternative mechanism to address the issue of non-compliance with treaty provisions and disputes over non-compliance, complemented by innovative institutional mechanisms. Thus, they occupy "a function between conciliation and traditional dispute settlement". See Sands and Peel (n 13) 161-162.

181 J Klabbers, 'Compliance Procedures' in D Bodansky, J Brunnée and E Hey (eds), The Oxford Handbook of International Environmental Law (OUP, Oxford 2007) 1008.
} 
when the environmental concerns exacerbate into security or military concerns, the effective reaction to them might no longer be possible. Therefore, the time for action is now. 